\title{
Synthesis, crystal structure, thermal and dielectric properties of tetrapropylammonium tetrabromozincate $\left[N\left(\mathrm{C}_{3} \mathbf{H}_{7}\right)_{4}\right]_{2}\left[\mathrm{ZnBr}_{4}\right]$ compound
}

\author{
Souad Chkoundali ${ }^{1}$ - Faouzi Hlel ${ }^{2}$ - Hamadi Khemekhem ${ }^{1}$
}

Received: 2 August 2016/Accepted: 22 November 2016/Published online: 1 December 2016

(c) The Author(s) 2016. This article is published with open access at Springerlink.com

\begin{abstract}
The new organic-inorganic compound tetrapropylammonium tetrabromozincate $\left[\mathrm{N}\left(\mathrm{C}_{3} \mathrm{H}_{7}\right)_{4}\right]_{2} \mathrm{ZnBr}_{4}$ has been synthesized and characterized by single-crystal X-ray diffraction, differential scanning calorimetry, IR, Raman and impedance measurements. The crystal structure refinement shows that the $\left[\mathrm{N}\left(\mathrm{C}_{3} \mathrm{H}_{7}\right)_{4}\right]_{2} \mathrm{ZnBr}_{4}$ compound is crystallized in the monoclinic system (space group $\mathrm{C}_{2 / \mathrm{c}}$ ) with the following unit cell parameters: $a=33.145(5) \AA, \quad b=14.234(3) \AA$, $c=15.081(2) \AA, \beta=110.207(5)^{\circ}$ and $Z=8$. The structural arrangement of the title compound can be described as an alternation of organic and inorganic layers along the [100] direction. Differential scanning calorimetry disclosed two order-disorder transition phases located at 340 and $393 \mathrm{~K}$. Besides, an analysis of the dielectric constants $\varepsilon^{\prime}$ and $\varepsilon^{\prime \prime}$, at several frequencies, shows a distribution of relaxation times. This relaxation is probably due to the reorientational dynamics of alkyl chains.
\end{abstract}

\section{Introduction}

Recently, attention has been drawn to a novel class of open-framework materials, namely organic-inorganic hybrid materials. These materials exhibit specific properties, such as electronic, optical, thermal and catalytic, since they combine both inorganic and organic properties [1, 2].

Souad Chkoundali

schkoundali@yahoo.fr

1 Laboratoire des Matériaux Multifonctionnels et Applications (LaMMA), Faculté des Sciences de Sfax, Université de Sfax, 3018 Sfax, Tunisia

2 Laboratoire de l'état Solide, Faculté des Sciences de Sfax, Université de Sfax, B.P. 802, 3018 Sfax, Tunisia
Inorganic materials offer the potential for a wide range of electronic properties, magnetic and dielectric transitions, substantial mechanical hardness and thermal stability, and the organic materials can provide high fluorescence efficiency, large polarizability and plastic mechanical properties [3, 4]. Moreover, the non-covalent interactions, usually observed in hybrid materials, are some of the most powerful forces to organize structural units in both natural and artificial systems, and they have important effects on the organization and properties of many materials in areas such as biology, crystal engineering and material science [5-9]. Considerable interest has been devoted to the compounds of the general formula $\mathrm{AMX}_{4}$, where $\mathrm{A}$ is an organic cation, $\mathrm{M}$ a divalent metal ( $\mathrm{M}$ : $\mathrm{Zn}, \mathrm{Cd}, \mathrm{Cu}, \mathrm{Mn} . .$.$) and \mathrm{X}$ a halogens ( $\mathrm{X}: \mathrm{Cl}, \mathrm{Br}$, and $\mathrm{I}$ ) can be described as a sequence of alternating organic-inorganic layers. Many of these compounds exhibit successive structural phase transitions, which are associated with the reorientational dynamics of organic and inorganic part.

In this context, the present work is devoted to the synthesis, crystal structure, IR, Raman, scanning calorimetry (DSC) and dielectric proprieties on a new tetrapropylammonium tetrabromozincate $\left[\mathrm{N}\left(\mathrm{C}_{3} \mathrm{H}_{7}\right)_{4}\right]_{2}\left[\mathrm{ZnBr}_{4}\right]$ sample.

\section{Experimental procedures}

White prismatic monocrystals of $\left[\mathrm{N}\left(\mathrm{C}_{3} \mathrm{H}_{7}\right)_{4}\right]_{2} \mathrm{ZnBr}_{4}$ compound are obtained by slow evaporation at room temperature of the aqueous solution formed by $\mathrm{ZnBr}_{2}$ (purity $98 \%$;) and $\left[\mathrm{N}\left(\mathrm{C}_{3} \mathrm{H}_{7}\right)_{4}\right] \mathrm{Br}$ (purity $97 \%$; FLUKA) in a molar ratio of $1: 1$. The reaction sequence for the synthesis is shown in the following equation:

$2\left[\mathrm{~N}\left(\mathrm{C}_{3} \mathrm{H}_{7}\right)_{4}\right] \mathrm{Br}+\mathrm{ZnBr}_{2} \stackrel{\mathrm{H}_{2} \mathrm{O}}{\longrightarrow}\left[\mathrm{N}\left(\mathrm{C}_{3} \mathrm{H}_{7}\right)_{4}\right]_{2} \mathrm{ZnBr}_{4}$ 
$\mathrm{X}$-ray structural analysis was performed on a single crystal selected with an optical microscope. The intensity data are collected on a Bruker AXS CCD area detector system equipped with graphite monochromatic $\mathrm{MoK}_{\alpha}$ radiation $(0.71073 \AA)$ at room temperature. A total of 6063 independent reflections were collected using the $\omega-2 \theta$ scan technique of which 2900 have $I>2 \sigma(I)$ and are used for the structure determination. Then, the structure was solved by the Patterson method using SHELXS-97 [10] and refined by SHELXL-97 [11] programs, which readily establishes the heavy atom positions and facilitates the identification of the light atoms from different Fourier maps. We note that four carbon atoms of $\left[\mathrm{N}(3)\left(\mathrm{C}_{3} \mathrm{H}_{7}\right)_{4}\right]^{+}$ cation are disordered. As soon as the duplication tentative of these atoms is not successful, the structure is solved with four constraints imposed on atom distances.

On the other hand, the calorimetric measurements are taken on PerkinElmer DSC-7 from 300 up to $440 \mathrm{~K}$ at an average heating of $5^{\circ}$ per min with $15 \mathrm{mg}$ sample weight. The infrared spectrum is obtained using a PerkinElmer FTIR 1000 spectrometer with a sample pressed in $\mathrm{KBr}$ pellet in the $450-4000 \mathrm{~cm}^{-1}$ region. The Raman spectrum of the sample is obtained under the microscope with a T-64000 Raman spectrometer (ISA, Jobin-Yvon) with nitrogen-cooled CCD detector, in the frequency $50-3500 \mathrm{~cm}^{-1}$ region with 1800 tr per mm.

The dielectrical measurements are taken using a twoelectrode configuration. In fact, the $\left[\left(\mathrm{C}_{3} \mathrm{H}_{7}\right)_{4} \mathrm{~N}\right]_{2} \mathrm{ZnBr}_{4}$ sample is pressed into pellets of $8 \mathrm{~mm}$ in diameter and $1.1 \mathrm{~mm}$ in thickness using $3 \mathrm{t} \mathrm{cm}^{-2}$ uniaxial pressures.

The AC impedance data, $\mid \mathrm{ZI}$, and phase angle are obtained in the frequency range of $20 \mathrm{~Hz}-1 \mathrm{MHz}$ using Agilent 4284A LCR impedance analyzer over the temperature range of 303-403 K.

\section{Results and discussion}

\subsection{Structure description}

At room temperature, the title compound crystallizes in the monoclinic system $\left(\mathrm{C}_{2 / \mathrm{c}}\right.$ space group) with the following unit cell parameters: $a=33.145(2) \AA, b=14.234(3) \AA$, $c=15.081(2) \AA$ and $\beta=110.23(0)^{\circ}$. Diamond computer program is used to prepare the drawings. The crystal data collected reflections and the parameters of the final refinement are gathered in Table 1. The interatomic bond distances and angle schemes are listed in Table 2. It should be mentioned that atomic coordinate anisotropic displacement parameters, tables for all bond distances, and angles are deposited at the Cambridge Crystallographic Data Center (deposition number CCDC 861352). The
Table 1 Crystal data and structure refinement for $\left[\mathrm{N}\left(\mathrm{C}_{3} \mathrm{H}_{7}\right)_{4}\right]_{2} \mathrm{ZnBr}_{4}$

\begin{tabular}{|c|c|}
\hline Formula & $\mathrm{N}_{2} \mathrm{C}_{24} \mathrm{H}_{56} \mathrm{ZnBr}_{4}$ \\
\hline Molecular weight $\left(\mathrm{g} \mathrm{mol}^{-1}\right)$ & 757 \\
\hline Color/shape & White/prismatic \\
\hline Space group & $C_{2 / \mathrm{c}}\left(\mathrm{N}^{\circ} 15\right)$ \\
\hline Crystal system & Monoclinic \\
\hline Temperature $(\mathrm{K})$ & 296 \\
\hline \multicolumn{2}{|l|}{ Unit cell dimensions } \\
\hline$a(\AA)$ & $33.145(5)$ \\
\hline$b(\AA)$ & $14.234(3)$ \\
\hline$c(\AA)$ & $15.081(2)$ \\
\hline$\beta\left({ }^{\circ}\right)$ & $110.207(5)$ \\
\hline Volume $\left(\AA^{3}\right), Z$ & $6677.1(17)$ \\
\hline $\begin{array}{l}\text { Absorption coefficient } \\
\left(\mathrm{mm}^{-1}\right)\end{array}$ & 3.862 \\
\hline Radiation type, $\lambda(\AA)$ & Mo K/ $\alpha, 0.71073$ \\
\hline Crystal size $\left(\mathrm{mm}^{3}\right)$ & $0.34,0.28,0.23$ \\
\hline$\theta$ range $\left(^{\circ}\right)$ & $1.31-25.37$ \\
\hline Range of $h, k, l$ & $\begin{array}{l}-39 \rightarrow 39,-15 \rightarrow 17 \\
-18 \rightarrow 15\end{array}$ \\
\hline Measured reflections & 19,356 \\
\hline Independent reflections & 6063 \\
\hline Reflections $>2 \sigma(I)$ & 2900 \\
\hline$R_{\text {int }}$ & 0.0463 \\
\hline Refinement on & $\mathrm{F}^{2}$ \\
\hline Number of refined parameters & 290 \\
\hline GOOF & 0.955 \\
\hline$R / \mathrm{w} R$ & $0.0499 / 0.130$ \\
\hline$\Delta \rho(\max ) / \Delta \rho(\min )\left(\mathrm{e} / \AA^{3}\right)$ & $0.899 /-0.585$ \\
\hline
\end{tabular}

crystallographic analysis of this compound reveals that the crystal structure of $\left[\left(\mathrm{C}_{3} \mathrm{H}_{7}\right)_{4} \mathrm{~N}\right]_{2} \mathrm{ZnBr}_{4}$ consists of one and two halves of $\left[\mathrm{N}\left[\left(\mathrm{C}_{3} \mathrm{H}_{7}\right)_{4}\right]^{+}\right.$and one of $\mathrm{ZnBr}_{4}$ inequivalent groups.

A view of the asymmetric unit of the structure showing the thermal ellipsoid atom mean-square displacements of non-hydrogen is depicted in Fig. 2. The structural arrangement of the title compound can be described as an alternation of organic and inorganic layers along the [100] direction, made up of $\left[\mathrm{N}\left(\mathrm{C}_{3} \mathrm{H}_{7}\right)_{4}\right]^{+}$and $\left[\mathrm{ZnBr}_{4}\right]^{2-}$ atom groups, as shown in Fig. 1, respectively. The inorganic groups are located in the (100) plane at $a=1 / 8$ and $3 / 8$ sandwiched between two different organics sheets. The first, which is localized at $a / 8$, is made up of $\left[\mathrm{N}(2)\left(\mathrm{C}_{3} \mathrm{H}_{7}\right)_{4}\right]^{+}$characterized by $\mathrm{C}_{1}$ punctual symmetry, whereas the second observed at the origin is formed by two inequivalent cations $\left[\mathrm{N}(1)\left(\mathrm{C}_{3} \mathrm{H}_{7}\right)_{4}\right]^{+}$and $\left[\mathrm{N}(3)\left(\mathrm{C}_{3} \mathrm{H}_{7}\right)_{4}\right]^{+}$. Both ammoniums present $\mathrm{C}_{2}$ punctual symmetry. The crystal package is provided by van der Waals and ionic interaction. 
Table 2 Principal intermolecular distances $(\AA)$ and angles $\left(^{\circ}\right)$ for anionic part $\left[\mathrm{ZnBr}_{4}\right]^{2-}$ and cationic part $\left[\mathrm{N}\left(\mathrm{C}_{3} \mathrm{H}_{7}\right)_{4}\right]^{+}$

\begin{tabular}{|c|c|c|c|}
\hline \multicolumn{2}{|l|}{ Distance } & \multicolumn{2}{|l|}{ Angles } \\
\hline \multicolumn{4}{|l|}{$\mathrm{ZnBr}_{4}^{2-}$} \\
\hline $\mathrm{Zn}-\mathrm{Br} 1$ & $2.430(2)$ & $\mathrm{Br} 4-\mathrm{Zn}-\mathrm{Br} 2$ & $108.91(7)$ \\
\hline $\mathrm{Zn}-\mathrm{Br} 2$ & $2.410(2)$ & $\mathrm{Br} 4-\mathrm{Zn}-\mathrm{Br} 3$ & $106.97(7)$ \\
\hline $\mathrm{Zn}-\mathrm{Br} 3$ & $2.425(2)$ & $\mathrm{Br} 2-\mathrm{Zn}-\mathrm{Br} 3$ & 109.67 \\
\hline \multirow[t]{3}{*}{$\mathrm{Zn}-\mathrm{Br} 4$} & $2.401(2)$ & $\mathrm{Br} 4-\mathrm{Zn}-\mathrm{Br} 1$ & $109.28(7)$ \\
\hline & & $\mathrm{Br} 2-\mathrm{Zn}-\mathrm{Br} 1$ & $109.77(7)$ \\
\hline & & $\mathrm{Br} 3-\mathrm{Zn}-\mathrm{Br} 1$ & $112.16(7)$ \\
\hline \multicolumn{4}{|l|}{$\mathrm{N}(1)\left(\mathrm{C}_{3} \mathrm{H}_{7}\right)_{4}^{+}$} \\
\hline N1-C11 & $1.513(11)$ & $\mathrm{C} 11-\mathrm{N} 1-\mathrm{C} 11^{\mathrm{a}}$ & $107.7(11)$ \\
\hline $\mathrm{N} 1-\mathrm{C} 14$ & $1.517(11)$ & $\mathrm{C} 11-\mathrm{N} 1-\mathrm{C} 14^{\mathrm{a}}$ & $110.3(6)$ \\
\hline $\mathrm{C} 15-\mathrm{C} 16$ & $1.505(15)$ & $\mathrm{C} 11-\mathrm{N} 1-\mathrm{C} 14^{\mathrm{a}}$ & $110.7(6)$ \\
\hline $\mathrm{C} 11-\mathrm{C} 12$ & $1.511(14)$ & $\mathrm{C} 11-\mathrm{N} 1-\mathrm{C} 14$ & $110.7(6)$ \\
\hline $\mathrm{C} 14-\mathrm{C} 15$ & $1.517(15)$ & $\mathrm{C} 11^{\mathrm{a}}-\mathrm{N} 1-\mathrm{C} 14^{\mathrm{a}}$ & $110.3(6)$ \\
\hline \multirow[t]{5}{*}{$\mathrm{C} 12-\mathrm{C} 13$} & $1.530(14)$ & $\mathrm{C} 14-\mathrm{N} 1-\mathrm{C} 14^{\mathrm{a}}$ & $107.1(11)$ \\
\hline & & $\mathrm{C} 12-\mathrm{C} 11-\mathrm{N} 1$ & $116.2(8)$ \\
\hline & & $\mathrm{C} 15-\mathrm{C} 14-\mathrm{N} 1$ & $117.0(9)$ \\
\hline & & $\mathrm{C} 11-\mathrm{C} 12-\mathrm{C} 13$ & $110.0(10)$ \\
\hline & & C16-C15-C14 & $110.6(10)$ \\
\hline \multicolumn{4}{|l|}{$\mathrm{N}(2)\left(\mathrm{C}_{3} \mathrm{H}_{7}\right)_{4}^{+}$} \\
\hline N2-C26 & $1.511(12)$ & $\mathrm{C} 211-\mathrm{C} 210-\mathrm{N} 2$ & $117.3(10)$ \\
\hline N2-C21 & $1.529(12)$ & $\mathrm{C} 21-\mathrm{C} 22-\mathrm{C} 23$ & $110.4(10)$ \\
\hline N2-C27 & $1.515(12)$ & $\mathrm{C} 26-\mathrm{C} 24-\mathrm{C} 25$ & $111.0(11)$ \\
\hline $\mathrm{N} 2-\mathrm{C} 210$ & $1.522(13)$ & $\mathrm{C} 24-\mathrm{C} 26-\mathrm{N} 2$ & $116.5(9)$ \\
\hline C210-C211 & $1.471(16)$ & $\mathrm{C} 29-\mathrm{C} 28-\mathrm{C} 27$ & $110.7(10)$ \\
\hline $\mathrm{C} 22-\mathrm{C} 21$ & $1.491(14)$ & $\mathrm{C} 22-\mathrm{C} 21-\mathrm{N} 2$ & $117.2(9)$ \\
\hline $\mathrm{C} 22-\mathrm{C} 23$ & $1.500(14)$ & C210-C211-C212 & $111.5(11)$ \\
\hline $\mathrm{C} 24-\mathrm{C} 26$ & $1.498(14)$ & $\mathrm{C} 26-\mathrm{N} 2-\mathrm{C} 27$ & $111.5(8)$ \\
\hline $\mathrm{C} 24-\mathrm{C} 25$ & $1.517(17)$ & $\mathrm{C} 26-\mathrm{N} 2-\mathrm{C} 210$ & $107.8(8)$ \\
\hline $\mathrm{C} 212-\mathrm{C} 211$ & $1.522(16)$ & $\mathrm{C} 27-\mathrm{N} 2-\mathrm{C} 210$ & $109.3(8)$ \\
\hline $\mathrm{C} 28-\mathrm{C} 29$ & $1.503(14)$ & $\mathrm{C} 26-\mathrm{N} 2-\mathrm{C} 21$ & $109.5(7)$ \\
\hline \multirow[t]{3}{*}{ C28-C27 } & $1.510(15)$ & $\mathrm{C} 27-\mathrm{N} 2-\mathrm{C} 21$ & $107.6(8)$ \\
\hline & & $\mathrm{C} 210-\mathrm{N} 2-\mathrm{C} 21$ & $111.1(8)$ \\
\hline & & $\mathrm{C} 28-\mathrm{C} 27-\mathrm{N} 2$ & $117.1(9)$ \\
\hline \multicolumn{4}{|l|}{$\mathrm{N}(3)\left(\mathrm{C}_{3} \mathrm{H}_{7}\right)_{4}^{+}$} \\
\hline N3-C34 & $1.409(15)$ & $\mathrm{C} 34-\mathrm{N} 3-\mathrm{C} 34^{\mathrm{b}}$ & $112.9(18)$ \\
\hline N3-C31 & $1.444(16)$ & $\mathrm{C} 34-\mathrm{N} 3-\mathrm{C} 31^{\mathrm{b}}$ & $109.8(12)$ \\
\hline C36-C35 & 1.369 (19) & $\mathrm{C} 34-\mathrm{N} 3-\mathrm{C} 31^{\mathrm{b}}$ & $110.3(8)$ \\
\hline C35-C34 & $1.335(17)$ & $\mathrm{C} 34-\mathrm{N} 3-\mathrm{C} 31^{\mathrm{b}}$ & $110.3(8)$ \\
\hline C33-C32 & $1.414(18)$ & $\mathrm{C} 34^{\mathrm{b}}-\mathrm{N} 3-\mathrm{C} 31^{\mathrm{b}}$ & $109.8(12)$ \\
\hline \multirow[t]{5}{*}{ C31-C32 } & $1.354(19)$ & $\mathrm{C} 31-\mathrm{N} 3-\mathrm{C} 31^{\mathrm{b}}$ & 103.3 \\
\hline & & C34-C35-C36 & $135(2)$ \\
\hline & & $\mathrm{C} 35-\mathrm{C} 34-\mathrm{N} 3$ & $141.0(18)$ \\
\hline & & C32-C31-N3 & $140.2(19)$ \\
\hline & & C33-C32-C31 & $120(2)$ \\
\hline
\end{tabular}

a $1-x, y, 1 / 2+z$

b $1-x, y, 3 / 2+z$

\subsubsection{Geometry of the $\mathrm{ZnBr}_{4}^{2-}$ anion}

The zinc atom is tetrahedrally coordinated by bromine atoms. The $\mathrm{Zn}-\mathrm{Br}$ bond lengths are from 2.401(2) to $2.430(2) \AA$. The $\mathrm{Br}-\mathrm{Zn}-\mathrm{Br}$ angles are in the range of 106.97(7)-112.16(7) ${ }^{\circ}$, as listed in Table 2. The average values of the distortion parameters of $\mathrm{ZnBr}_{4}^{2-}$ tetrahedron are calculated, respectively, using Eqs. (1) and (2) [12]:

$\mathrm{ID}(\mathrm{Br}-\mathrm{Zn}-\mathrm{Br})=\sum_{i=1}^{n 1} \frac{|a i-a m|}{n 1 a m}$

$\mathrm{ID}(\mathrm{Zn}-\mathrm{Br})=\sum_{i=1}^{n 2} \frac{|d i-d m|}{n 2 d m}$

with $a$ : $(\mathrm{Br}-\mathrm{Zn}-\mathrm{Br})$ angle, $d$ : $(\mathrm{Zn}-\mathrm{Br})$ distance, $m$ : average values, $n 1=4$ and $n 2=6$. ID $(\mathrm{Zn}-\mathrm{Br}-\mathrm{Zn})=0.009$, ID $(\mathrm{Zn}-\mathrm{Br})=0.0042$. The low values of the distortion indices indicate that the coordination geometry of the metal is pseudo-regular tetrahedron.

\subsubsection{Geometry of the $\left(\mathrm{C}_{3} \mathrm{H}_{7}\right)_{4} \mathrm{~N}^{+}$cation}

The organic part of $\left[\mathrm{N}\left(\mathrm{C}_{3} \mathrm{H}_{7}\right)_{4}\right]_{2} \mathrm{ZnBr}_{4}$ compound shows three inequivalent cations: $\mathrm{N}(1)\left(\mathrm{C}_{3} \mathrm{H}_{7}\right)_{4}^{+}, \mathrm{N}(2)\left(\mathrm{C}_{3} \mathrm{H}_{7}\right)_{4}^{+}$and $\mathrm{N}(3)\left(\mathrm{C}_{3} \mathrm{H}_{7}\right)_{4}^{+}$with $\mathrm{C}_{2}, \mathrm{C}_{1}$ and $\mathrm{C}_{2}$ punctual symmetry, respectively, as shown in Figs. 3 and 4. The details of the principal inter-atomic distances and angles are gathered in Table 2. Chain alkyls of the first cation show a trans configuration, whereas other cations are in gauche configuration. With the exception of the third cation, the $\mathrm{CC}$ and $\mathrm{CN}$ distances and $\mathrm{C}-\mathrm{N}-\mathrm{C}, \mathrm{C}-\mathrm{C}-\mathrm{C}$ and $\mathrm{C}-\mathrm{C}-\mathrm{N}$ angles are normal and usually observed. The observed distances and angles $\mathrm{N}(3)\left(\mathrm{C}_{3} \mathrm{H}_{7}\right)_{4}^{+}$are more dispersed and vary from 1.335 to $1.444 \AA$ and from $103.3^{\circ}$ to $141.0^{\circ}$, respectively. This dispersion is related to the disorder of this cation. In the literature, the range of distances and angles is observed on other chain alkyls.

\subsection{Calorimetric study}

Figure 5 shows the DSC runs for $\left[\left(\mathrm{C}_{3} \mathrm{H}_{7}\right)_{4}\right]_{2} \mathrm{ZnBr}_{4}$ upon the heating a sample $(15 \mathrm{mg})$ with a scanning rate $\left(5^{\circ} \mathrm{min}^{-1}\right)$. An overview of the results obviously shows the existence of two distinct endothermic peaks detected at 340 and $393 \mathrm{~K}$ corresponding to the phase transition. Enthalpy and entropy of the first phase transition are $3.838 \mathrm{k} \mathrm{J} \mathrm{mol}^{-1}$ and $11.32 \mathrm{~J} \mathrm{~mol}^{-1} \mathrm{~K}^{-1}$, respectively. However, those of the second phase transition are $4.101 \mathrm{k} \mathrm{J} \mathrm{mol}^{-1}$ and $10.41 \mathrm{~J} \mathrm{~mol}^{-1} \mathrm{~K}^{-1}$, respectively. These experimentally observed entropies can be interpreted in terms of Boltzmann's principle $\Delta S=R \operatorname{Ln} \Omega=R \operatorname{Ln} N 1 \mathrm{~W} 2$ where $N 1$ 
Fig. 1 [010] view showing alternation of organic and inorganic sheets of $\left[\mathrm{N}\left(\mathrm{C}_{3} \mathrm{H}_{7}\right)_{4}\right]_{2} \mathrm{ZnBr}_{4}$
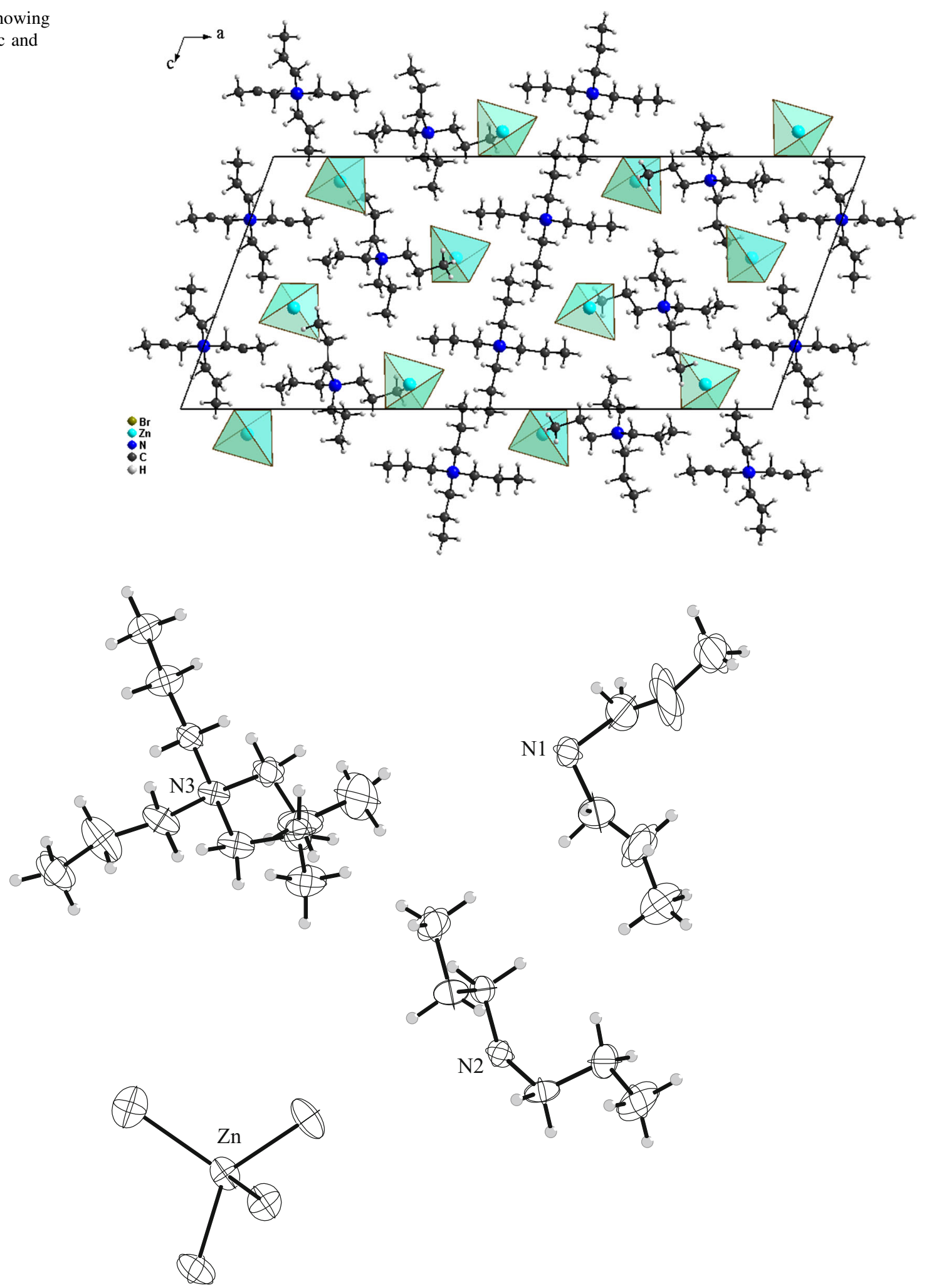

Fig. 2 Representation of asymmetric unit with $50 \%$ probability of the thermal ellipsoid of non-hydrogen atoms of $\left[N\left(\mathrm{C}_{3} \mathrm{H}_{7}\right)_{4}\right]_{2} \mathrm{ZnBr}$

and $N 2$ are the number of distinguishable orientations allowed in the high- and low-temperature phases [13]. At 340 and $393 \mathrm{~K}$, the $N \mathrm{l} / N 2$ ratio is equal to 4 and 3.5 , respectively. Taking into account the transition entropy values, both phase transitions may be classified as "orderdisorder" phase transition. 


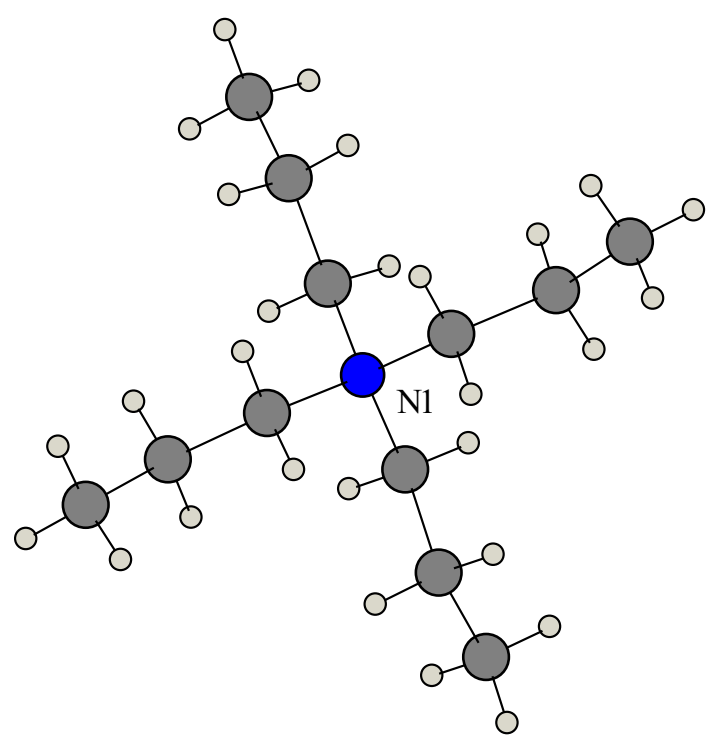

Fig. 3 TPAZnBr $N 1$ cross-configuration

\subsection{Infrared and Raman spectra}

To gain more information about the crystal structure, we have undertaken a vibrational study using infrared spectroscopy and Raman scattering. The infrared and Raman spectra of the studied compound at room temperature are shown in Figs. 6 and 7, respectively. The assignments of the observed bands are realized by comparison with similar compounds [14-20]. Besides, the wave numbers of the registered peaks are quoted in Table 2 . The bands observed at 2969 and $2988 \mathrm{~cm}^{-1}$ in IR and Raman, respectively, are accredited to the asymmetric $v_{a s}\left(\mathrm{CH}_{3}\right)$ stretching mode. Concerning the $\mathrm{CH}$ stretching vibrations $\mathrm{v}_{\mathrm{s}}\left(\mathrm{CH}_{2}\right)+\mathrm{v}_{\mathrm{s}}(-$ $\mathrm{CH}_{3}$ ), they are observed at $2881 \mathrm{~cm}^{-1}$ in IR. The band that appears at 1469 and $1463 \mathrm{~cm}^{-1}$ in IR and Raman, respectively, is related to the asymmetric deformation $\delta_{\text {as }}\left(\mathrm{CH}_{3}\right)$, whereas the bands that appeared at 1376 and $1326 \mathrm{~cm}^{-1}$ in
IR can be assigned to the symmetric deformation $\delta_{\mathrm{s}}\left(\mathrm{CH}_{3}\right)$ and to the $\omega\left(\mathrm{CH}_{2}\right)$ wagging modes, respectively, while the weak bands observed around 1173 are assigned to the $\rho r$ $\left(\mathrm{CH}_{3}\right)$ methyl rocking modes $[16,26]$. The frequencies observed at 1177 and $852 \mathrm{~cm}^{-1}$ in infrared are related to the rocking $\rho_{\mathrm{r}}\left(\mathrm{CH}_{3}\right)$ vibration modes. The splitting $(\mathrm{C}-\mathrm{C}-\mathrm{C}-\mathrm{N})$ and the blending mode at $1134 \mathrm{~cm}^{-1}$ may correspond to different conformers of organic chains. The bands observed at $1116 \mathrm{~cm}^{-1}$ are assigned to $v_{1}\left(\mathrm{NC}_{4}\right)$ stretching modes. Moreover, the weak peak in the infrared spectrum at $1044 \mathrm{~cm}^{-1}$ is related to the bending mode $\left[\mathrm{v}_{\mathrm{s}}(\mathrm{C}-\mathrm{C}-\mathrm{N})\right.$ ] [21-25]. The band observed around 970 and at $921 \mathrm{~cm}^{-1}$ is assigned to $\mathrm{v}_{1}\left(\mathrm{NC}_{4}\right)$ stretching modes. A weak band that appeared at $874 \mathrm{~cm}^{-1}$ is related to the $\rho_{\mathrm{r}}\left(\mathrm{CH}_{3}\right)+\rho_{\mathrm{r}}\left(\mathrm{CH}_{2}\right)$ rocking vibration mode [16]. The deformation mode $v_{3}\left(\mathrm{NC}_{4}\right)$ appears at $762 \mathrm{~cm}^{-1}$ in IR. The deformation mode $v_{2}\left(\mathrm{NC}_{4}\right)$ appears below $750 \mathrm{~cm}^{-1}$. The band observed at $515 \mathrm{~cm}^{-1}$ in IR is accredited to the $v_{11}\left(\mathrm{~B}_{2 \mathrm{~g}}\right)$ stretching mode. The bands corresponding to the internal vibrational modes of the anions: $v_{1}, v_{2}, v_{3}$ and $v_{4}\left(\mathrm{ZnX}_{4}\right)$ (where $\mathrm{X}=\mathrm{Cl}$ and $\mathrm{Br}$ ) appear in the spectral region below $300 \mathrm{~cm}^{-1}$. The band appearing at $193 \mathrm{~cm}^{-1}$ is assigned to the $v_{3}\left(\mathrm{ZnBr}_{4}\right)$ mode and can be used to confirm the presence of the $\mathrm{ZnBr}_{4}$ group in this compound.

\subsection{Dielectric properties}

The temperature dependence of the real $\varepsilon^{\prime}$ and imaginary $\varepsilon^{\prime \prime}$ parts of the dielectric permittivity of $\mathrm{TPA}_{2} \mathrm{ZnBr}_{4}$ at different frequencies is shown in Figs. 8 and 9, respectively. It is clear from these figures that there are three regions, region I $(T<340)$, region II $(340<T<393)$ and region III $(T>393)$.

At $T<340$, the variations of $\varepsilon^{\prime}$ and $\varepsilon^{\prime \prime}$ with temperature are almost constant. This may be explained by the restricted reorientational motions of the cation, which
Fig. $4 \mathrm{TPAZnBr} N 2$ and $N 3$ broken configuration
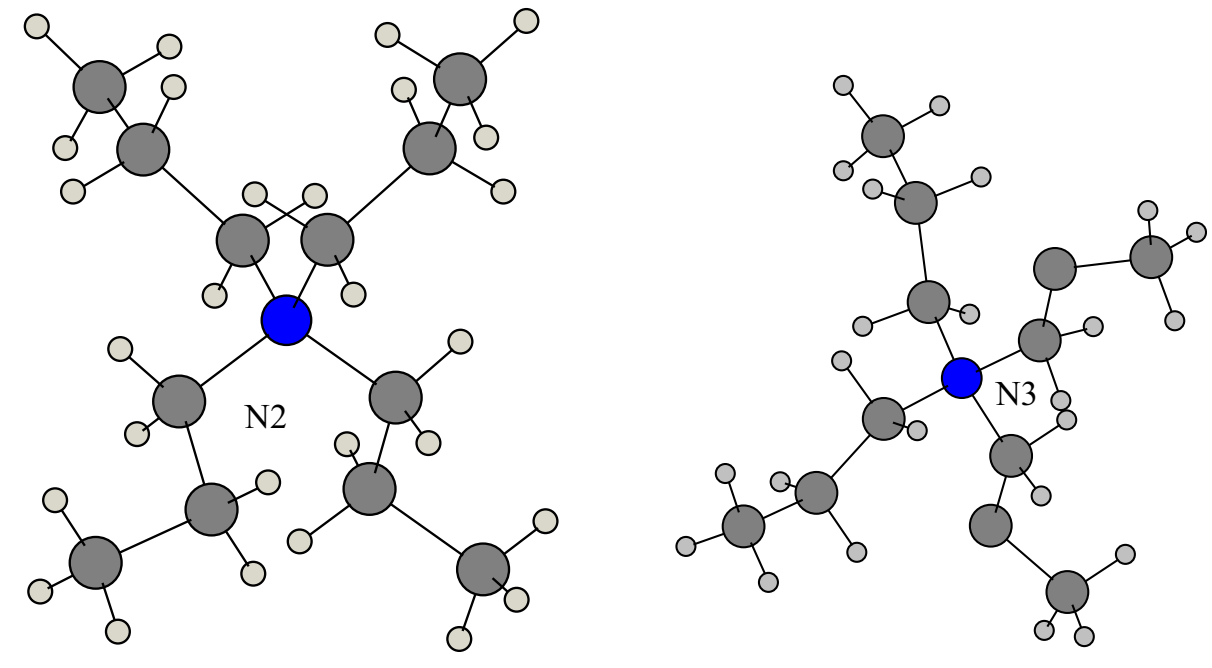


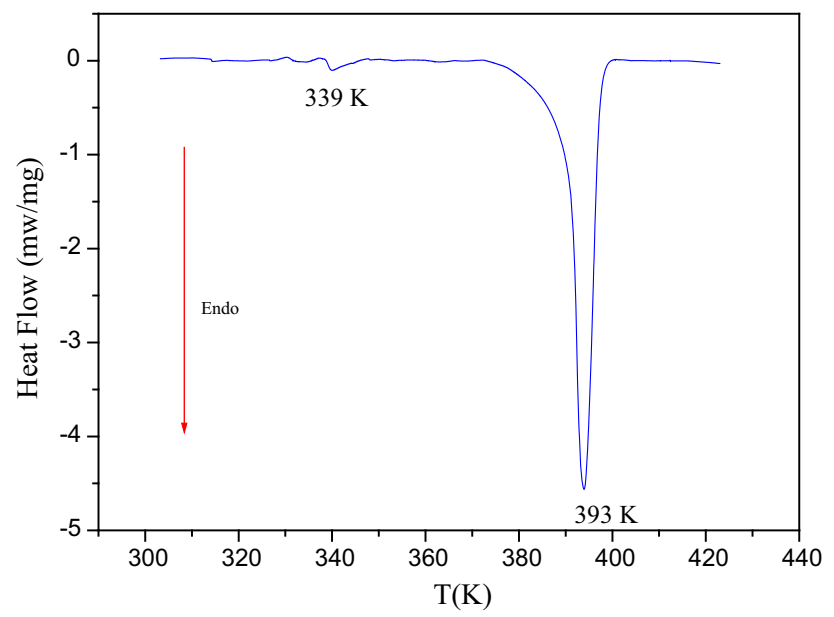

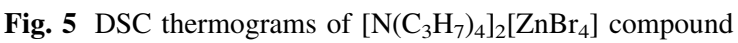

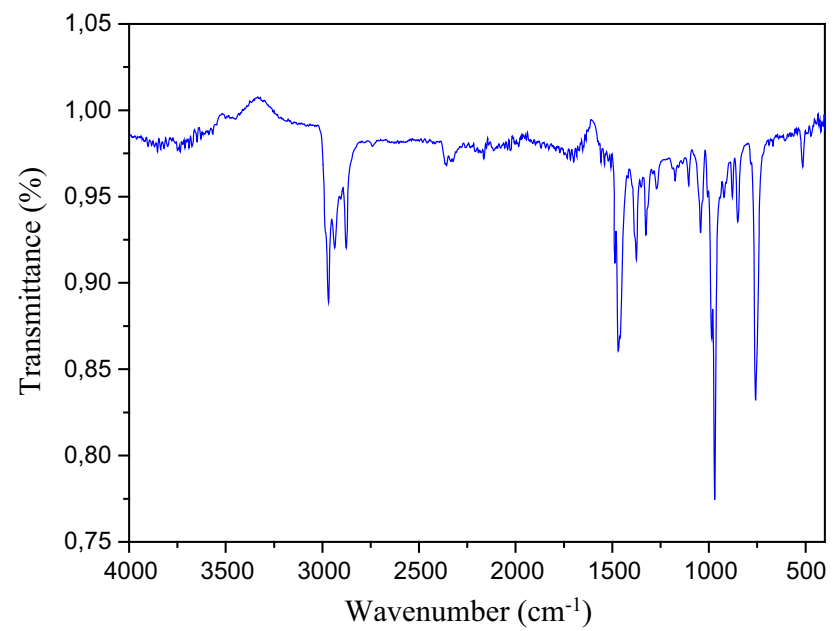

Fig. 6 Infrared spectrum of $\left[\mathrm{N}\left(\mathrm{C}_{3} \mathrm{H}_{7}\right)_{4}\right]_{2}\left[\mathrm{ZnBr}_{4}\right]$ compound

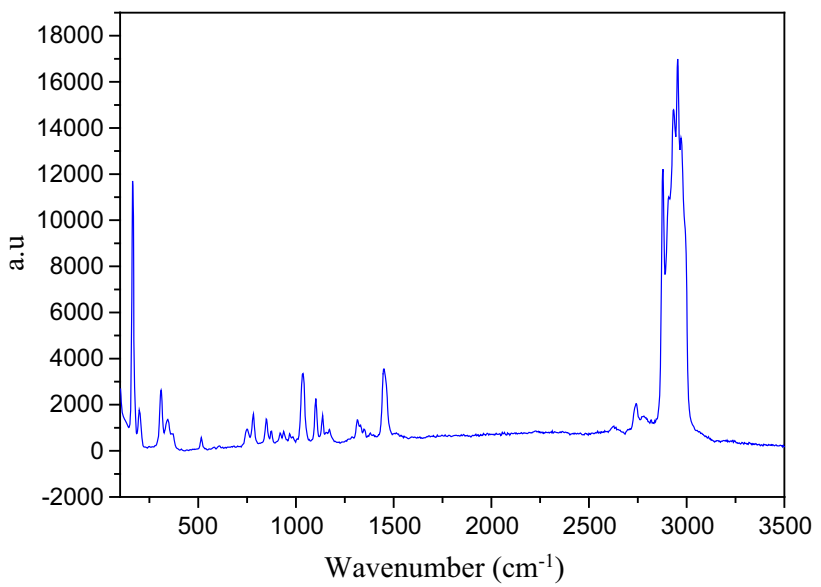

Fig. 7 Raman spectra of $\left[\mathrm{N}\left(\mathrm{C}_{3} \mathrm{H}_{7}\right)_{4}\right]_{2}\left[\mathrm{ZnBr}_{4}\right]$

cannot orient themselves with respect to the direction of the applied electric field, but they acquire a weak contribution to polarization.

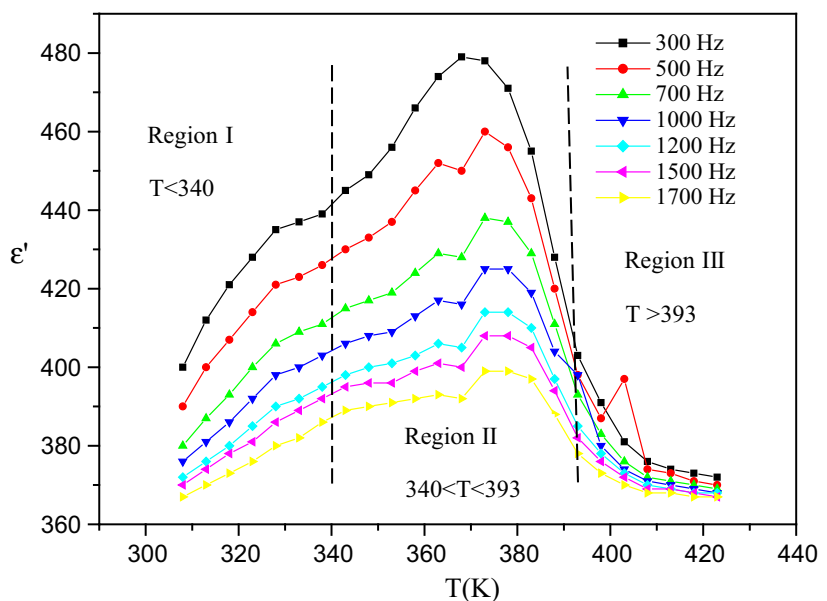

Fig. 8 Temperature dependence of the real part of the permittivity at various frequencies

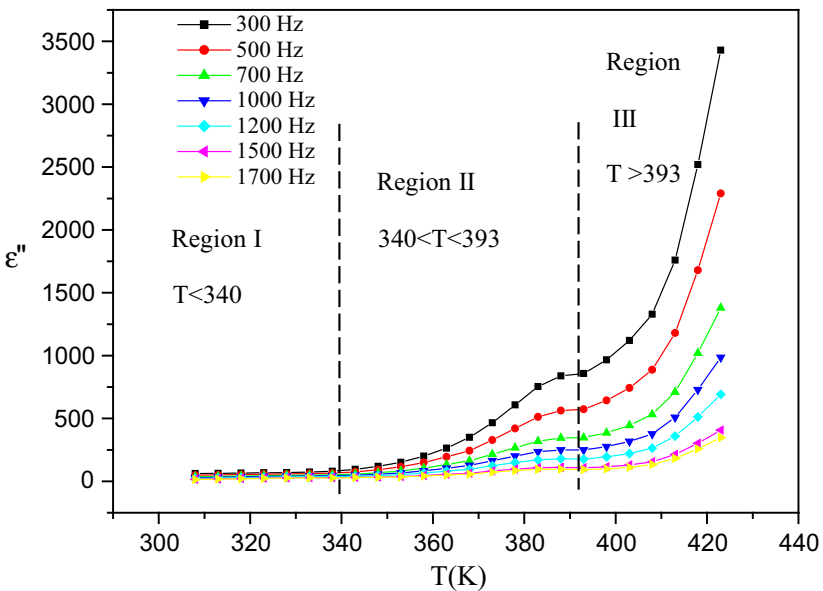

Fig. 9 Temperature dependence of the imaginary part of the permittivity at various frequencies

Over the transition temperature, $T>340 \mathrm{~K}$, the reorientational dynamics of alkyl chains is activated. The cation gets enough excitation thermal energy to be able to obey the change in the external electric field more easily. This in return enhances their contribution to the polarization leading to an increase in dielectric behavior.

At $T>393$, an asymmetrical dielectric loss peak is observed. This anomaly may be due to disorder in the lattice caused by the reorientational motion of the alkyl chains [27], which weakens the van der Waals interaction between the ions that departs to another unit cell and leaves a vacancy behind [28].

This dielectric anomaly appears when the jumping frequency of localized charge carriers becomes approximately equal to that of the externally applied in the electric field. Furthermore, as the frequency increases, the peak located at $393 \mathrm{~K}$ becomes less pronounced. This can be explained by the fact that beyond a certain frequency of external field, 


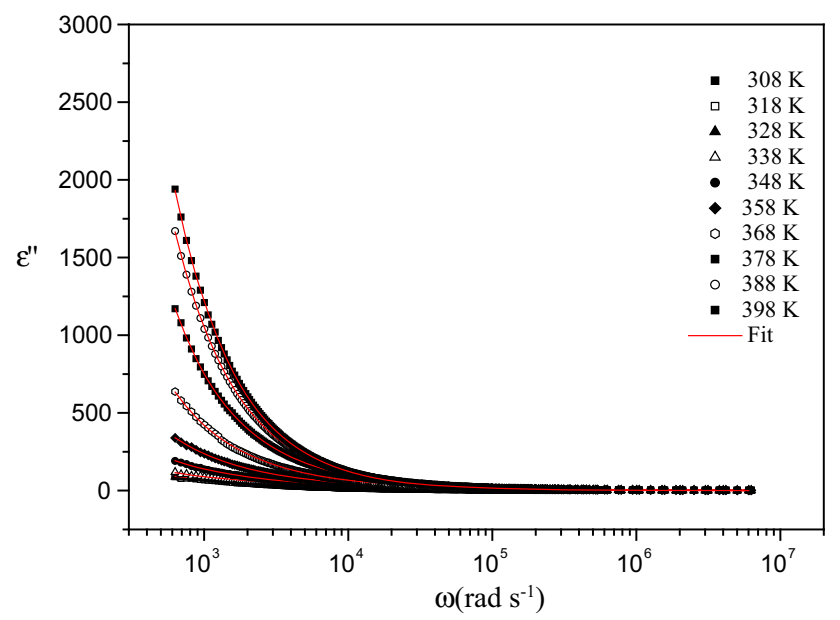

Fig. 10 Variation of $\ln \varepsilon^{\prime \prime}$ versus $\ln \omega$ at different temperatures

the charge carriers cannot follow the alternating electric field.

The dielectric relaxation is described by a non-Debye model, which gives the frequency a dependent complex permittivity in the form of $[29,30]$ :

$\varepsilon^{*}(\omega)=\varepsilon_{\infty}+\frac{\varepsilon_{\mathrm{s}}-\varepsilon_{\infty}}{1+\left(j \frac{\omega}{\omega_{1}}\right)^{1-\alpha}}+\frac{\sigma_{0}}{j \varepsilon_{0} \omega}$

The imaginary part of $\varepsilon^{*}$ is:

$\varepsilon^{\prime \prime}(\omega)=\frac{\left(\varepsilon_{\mathrm{s}}-\varepsilon_{\infty}\right)\left(\frac{\omega}{\omega_{1}}\right)^{1-\alpha} \sin \left(\frac{(1-\alpha) \pi}{2}\right)}{1+2\left(\frac{\omega}{\omega_{1}}\right)^{1-\alpha} \cos \left(\frac{(1-\alpha) \pi}{2}\right)+\left(\frac{\omega}{\omega_{1}}\right)^{2(1-\alpha)}}+\frac{\sigma_{0}}{\varepsilon_{0} \omega}$

where $\varepsilon_{\mathrm{s}}$ is the static permittivity, $\varepsilon_{\infty}$ is the permittivity at "infinitely" high frequency, $\varepsilon_{0}$ is the permittivity of the free space, $\sigma_{0}$ represents the specific conductivity, parameter $\alpha$ represents the tilting angle $(\alpha \cdot \pi / 2)$ of the circular arc from the real axis in the complex permittivity plane and $\omega$ is the frequency.

The first part in Eq. (4) is related to the thermal polarization and the second one to the electrical conductivity. Figure 10 shows the evolution of $\varepsilon^{\prime \prime}$ as a function of frequency at different temperatures. This figure shows that the imaginary part of permittivity has a low-frequency dispersive behavior when temperature increases [31]. There are no appreciable relaxation peaks in the frequency range employed in this study. Using function (4) gives a suitable fitting of the curves resulting from the experimental data.

Figure 11 shows the tangent losses, $\tan \delta=\varepsilon^{\prime \prime}(\omega) / \varepsilon^{\prime}(\omega)$, as a function of temperatures at different frequencies. All the curves show a similar behavior that the variation of real and imaginary parts of dielectric (the presence of three

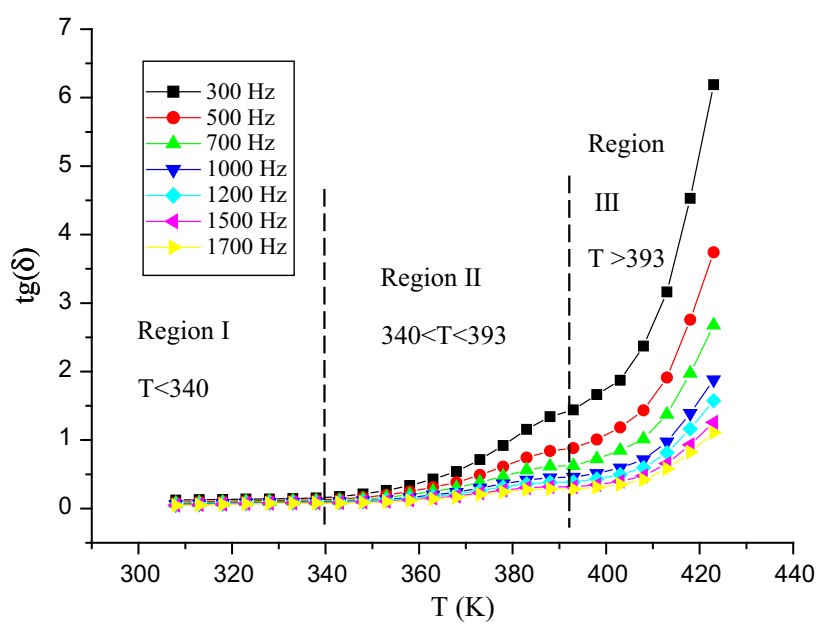

Fig. 11 Temperature dependence of the dielectric loss at various frequencies

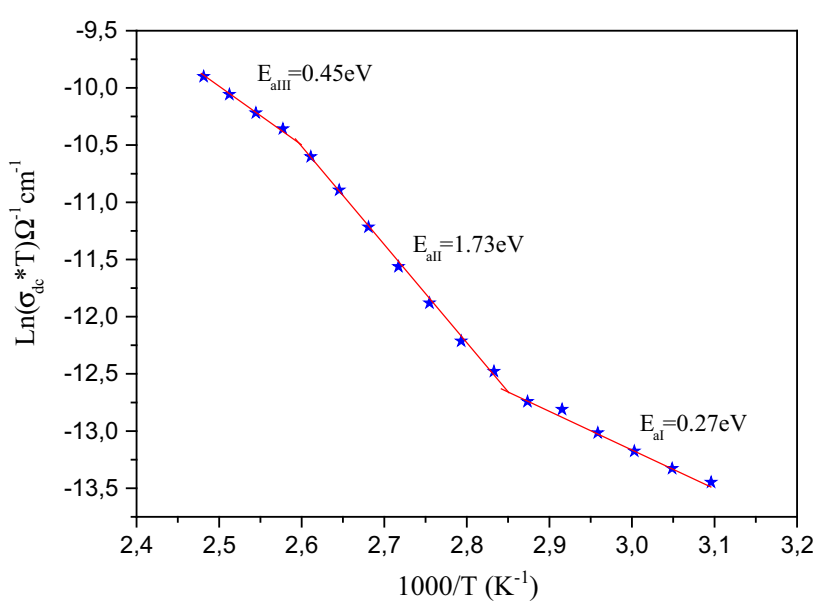

Fig. 12 Temperature dependence of $\ln \left(\sigma_{\mathrm{dc}} T\right)$

regions, region $\mathrm{I}(T<340)$, region $\mathrm{II}(340<T<393)$ and region III $(T>393))$.

Figure 12 shows the variation of $\log \left(\sigma_{\mathrm{dc}} T\right)$ with the inverse of absolute temperature $(1000 / T)$. This plot is explained by Arrhenius type. The change in the slope of the linear curve is detected around 340 and $393 \mathrm{~K}$. This discontinuity is in agreement with the DSC measurements. The values of the activation energies determined in regions I, II and III are 0.27 and 1.73 and $0.45 \mathrm{eV}$, respectively.

\section{Conclusion}

The present work is devoted to the synthesis of X-ray characterization and dielectric properties of tetrapropylammonium tetrabromozincate, $\left[\mathrm{N}_{(}\left(\mathrm{C}_{3} \mathrm{H}_{7}\right)_{4}\right]_{2}\left[\mathrm{ZnBr}_{4}\right]$. The compound crystallizes at room temperature in the monoclinic system (space group $\mathrm{C}_{2 / \mathrm{c}}$ ). The structural 
arrangement of the title compound can be described as alternation of organic and inorganic layers along the [100] direction, made up of $\left[\mathrm{N}\left(\mathrm{C}_{3} \mathrm{H}_{7}\right)_{4}\right]^{+}$and $\left[\mathrm{ZnBr}_{4}\right]^{2-}$ groups. The inorganic groups are located in the (100) plane at $a=1 / 8$ and $3 / 8$ sandwiched between two different organics sheets. The crystal package is provided by van der Waals and electrostatic interaction. Differential scanning calorimetry revealed the presence of two order-disorder phase transitions at 340 and $393 \mathrm{~K}$, resulting from the disorder of tetrapropylammonium cations. The results of the dielectric permittivity study confirm the conclusion drawn from the calorimetric measurements that the orderdisorder phase transition located in the vicinity of the temperature of the dielectric relaxation is characterized by change in the dynamical state of the cations.

Open Access This article is distributed under the terms of the Creative Commons Attribution 4.0 International License (http://crea tivecommons.org/licenses/by/4.0/), which permits unrestricted use, distribution, and reproduction in any medium, provided you give appropriate credit to the original author(s) and the source, provide a link to the Creative Commons license, and indicate if changes were made.

\section{References}

1. A.M. Fonseca, C.J.R. Silva, N. Nunes, I.C. Neves, J. Alloys Compd. 454, 72 (2008)

2. Z. Peng, X. Xing, X. Chen, J. Alloys Compd. 425, 323 (2006)

3. D.B. Mitzi, K. Chondroudis, C.R. Kagan, IBM J. Res. Dev. 45, $29(2001)$

4. I. Chaabane, F. Hlel, K. Guidara, J. Alloys Compd. 461, 495 (2008)

5. B. Gaweł, W. Łasocha, M. Zięba, J. Alloys Compd. 442, 77 (2007)

6. K.M. Guckian, B.A. Schweitzer, R.X.F. Ren, C.J. Sheils, D.C. Tahmassebi, E.T. Kool, J. Am. Chem. Soc. 122, 2213 (2000)

7. S.-Y. Mao, Y. Xie, Z.-X. Xie, L.-S. Zheng, J. Alloys Compd. 456, $534(2008)$

8. A.L. Gillon, A.G. Orpen, J. Starbuck, X.M. Wang, Y. RodriguezMartin, C. Ruiz-Perez, Chem. Commun. 22, 2287 (1999)

9. L. Brammer, J.C. Mareque Rivas, R. Atencio, S. Fang, F.C. Pigge, Chem. Soc. Dalton Trans. 21, 3855 (2000)
10. G.M. Sheldrick, in Crystallographic Computing, ed. by G.M. Sheldrick, C. Kruger, R. Goddard, 3, (Oxford University Press, Oxford, 1985)

11. G.M. Sheldrick, SHELXL 97 (Program for Crystal Structure Refinement University of Göttingen, Göttingen, 1997)

12. K. Brandenburg, M. Berndt DIAMOND. Version 2. 1. b. Crystal Impact Gb R, Bonn (1999)

13. A. Piecha, A. Gagor, A. Pietraszko, R. Jakubas, J. Solid State Chem. 183, 3058 (2010)

14. A. BenRhaiem, F. Hlel, K. Guidara, M. Gargouri, Spectrochim. Acta, Part A 66, 1107 (2007)

15. N. Hannachi, K. Guidara, A. Bulou, F. Hlel, Mater. Res. Bull. 45, 1754 (2010)

16. A. Oueslati, I. Chaabane, K. Adil, F. Hlel, J. Chem. 2013, 1 (2012)

17. M. Gosniowska, Z. Ciunik, G. Bator, R. Jakubas, J. Baran, J. Mol. Struct. 555, 243 (2000)

18. M. Karbowiak, J. Hanuza, J. Janczak, J. Drożdżyński, J. Alloy. Compd. 225, 338 (1995)

19. D. Lin-Vien, N.B. Colthup, W.G. Fateley, J.G. Grasselli, The Handbook of Infrared Raman Characteristic Frequencies of Organic Molecules (Academic Press, San Diego, 1991)

20. K. Nakamoto, Infrared Raman Spectra of Inorganic and Coordination Compounds, 5th edn. (Wiley, New York, 1997)

21. Y. Nishihata, A. Sawada, Acta Cryst. C 49, 1939 (1993)

22. J. Baran, M. Sled z, M. Drozd, A. Pietraszko, A. Haznar, H. Ratajczak, J. Mol. Struct. 526, 361 (2000)

23. M.A. Kandhaswamy, V. Srinivasan, Bull. Mater. Sci. 25, 41 (2002)

24. J.R. Durig, C. Zheng, G.A. Guirgis, H. Zhen, A.S. Drew, D.T. Durig, J. Mol. Struct. 786, 9 (2006)

25. M. Herstedt, W.A. Henderson, M. Smironov, L. Ducasse, L. Sevant, D. Talga, J.C. Lassègu, J. Mol. Struct. 783, 145 (2006)

26. A. Ouasri, A. Rhandour, M.C. Dhamelincourt, P. Dhamelincout, A. Mazzah, Spectochim. Acta Part A 58, 2779 (2002)

27. A. Piecha, A. Gagor, M. Weclawik, R. Jakubas, W. Medycki, Mater. Res. Bull. 48, 151 (2013)

28. ShA Mansour, I.S. Yahia, F. Yakuphanoglu, Dyes Pigm. 87, 144 (2010)

29. K. Sambasiva Rao, D.M. Prasad, P.M. Krishna, B. Tilak, K.C. Varadarajulu, Mater. Sci. Eng. 133, 141 (2006)

30. R. Ayouchi, D. Leien, F. Martin, M. Gabas, E. Dalchiele, J.R. Ramos-Barrodo, Thin Solid Films 426, 68 (2003)

31. K.S. Rao, P.M. Krishna, D.M. Prasad, J.H. Lee, J.S. Kim, J. Alloys Compd. 464, 497 (2008) 